\title{
A Corpus-based Approach toward Teaching Collocation of Synonyms
}

\author{
Ali Akbar Jafarpour \\ English Department, Shahrekord University, Shahrekord, Iran \\ Mahmood Hashemian \\ English Department, Shahrekord University, Shahrekord, Iran \\ Sepideh Alipour \\ English Department, Shahrekord University, Shahrekord, Iran
}

\begin{abstract}
L2 classes. The study aimed at comparing the effects of the corpus-based approach with the effects of the traditional approach on learning collocations of near-synonymous pairs. The study was run on 2 groups of $L 2$ learners. One group named experimental group studied with concordancing and the other group named the control group studied with the traditional approach. The participants in each group were similar in terms of their proficiency and collocation competence. During the study, the first group was taught through concordancing materials taken from BNC as the concordancing, whereas the control group was taught the collocations explicitly. The instruments used for data collection were a pretest, a posttest, a prewriting and a postwriting. Through running a $t$ test and descriptive statistics, the results revealed a difference between the two approaches about their effect on the comprehension and production of collocations of synonyms. The study has some implications for L2 learning and teaching that are discussed in the last part of the study.
\end{abstract}

Index Terms - collocation, synonym, corpus-based approach, traditional approach, writing

\section{INTRODUCTION}

Collocations are stable forms of language consisting of two or more than two words. According to Firth (1957, p. 181), "collocations of a given word are statements of the habitual or customary places of that word." Collocations abound in the English language, and their importance for L2 teaching and learning has been increasingly recognized. It might be admitted that collocations have not yet been generally integrated into L2 teaching materials and, as a consequence, not been given serious consideration in English classrooms (Souza Hodne, 2009). According to Nesselhauf (2003, cited in Souza Hodne, 2009), teaching of collocations as well as the difficulties that L2 learners have with collocations is not investigated well yet. By the invention of concordancing, concordancing is used for lexicography (Sinclair, 1991), L2 research (Carter \& McCarthy, 1999), and L2 teaching (Lewis, 1997). Concordancing has been used for the following purposes: studying multiple meanings of words and comparing the collocations of nearsynonyms (Chan, 2002). But according to Souza Hodne (2009), relatively few studies have associated corpora, teaching, and textbooks. Chambers (2005) observes a need for integrating corpora into L2 teaching, confirming that corpus consultation will become a complement to textbooks.

Writing has always been demanding and difficult for L2 learners. According to Celce-Murcia and Olshtain (2000, p. 141), even skilled L2 learners have problems writing. One of the problems of these learners is the use of collocations (Brashi, 2005; Parastuti, 2008). Zhang (1993) stated that collocations are the parameter of L2 learners' writing quality. He further suggested that the use of collocations distinguishes between good and poor and native and nonnative writings.

Another problem of L2 learners is the application of near-synonyms, especially their collocations. Near-synonyms are pairs of words with similar meanings, but different collocations. Strong and powerful are two examples of nearsynonyms. Tea can be strong, but not powerful (Zarei \& Gholami, 2007). The semantic differences and implications of synonyms are not easily recognized and often fail to be acquired by L2 learners

So, this study aimed to investigate the production and comprehension of collocations of near-synonyms, and the following research questions were formulated:

1. Is there any significant difference between the effects of the corpus-based approach and the traditional approach on L2 learners' comprehension of collocations of near-synonyms?

2. Can corpus-based approach improve L2 learners' production of collocations?

These following null hypotheses were also formulated in line with the above questions:

- $\mathrm{H}_{01}$ : There is no difference between the effects of the corpus-based approach and the traditional approach on L2 learners' comprehension of collocations of near-synonyms.

- $\mathrm{H}_{02}$ : Corpus-based approach cannot improve L2 learners' production of collocations. 


\section{BACKGROUND TO THE STUDY}

Firth (1957, p. 181) coined the word collocation, when he said "you shall know a word by the company it keeps." Collocations were given more attention when he said that the words get their meanings in combination with other words.

There are many definitions of collocations that overlap to some extent. Palmer (1933) defines collocations as the combination of more than one word that must be learned as a whole, not in isolation. Sinclair (2003) defined collocations as the combination of two items for the production of native-like language.

The concept of collocation includes lexical collocations and grammatical ones. Grammatical collocations are those that consist of an open class word (noun, adjective, and verb) and a preposition or grammatical structure such as an infinitive or clause (Benson et al., 1997). They recognize the following types of grammatical collocations:

- Noun + preposition: admiration for

- Noun + infinitival to: feel a need to do something

- Noun + that-clause: they reached an argument that they will do it.

- Preposition + noun: by chance

- Adjective + preposition: fond of music

- Adjective + infinitival to: it is important to go there

- Adjective + that-clause: they were sorry that she had an accident

Lexical collocations, on the other hand, do not include grammatical structures like prepositions. Nouns, adjectives, verbs, and adverbs are parts of lexical collocations. Some examples of this category are compose music, and make an impression.

Grammatical competence, communicative competence, and collocational competence are some competencies involved in learning an L2. Collocational competence is often neglected in the area of L2 learning. Lewis (2000) argued that L2 learners may be good at the area of communicative competence, but they need to increase their collocation competence.

In order to be able to speak idiomatic English, L2 learners need to know many collocations (Bahns \& Eldaw, 1993). He also stated that it would not be necessary for L2 learners to use many collocations in speech or writing, but that knowing the right collocations and using them in a right way is more important.

\section{A. Concordancing and L2 Teaching and Learning}

Concordancing has made changes in L2 teaching and learning. It has also changed the way of language teaching and learning (Cheng et al., 2004). The use of concordancing is a way to show that L2 learners can have access to authentic language through corpus and they can discover language patterns (Bernardini, 2002; Johns, 1991). The corpora can, for instance, be used for developing learning activities. According to Granath (2000, cited in Bernardini, 2004), corpora can be used in grammar and some other aspects of language. Tribble and Jones (1990) argued that concordancing shows authentic examples of different parts of a language and helps L2 learners to discover different meanings, usages, and collocations of different words.

The corpus approach is the use of concordancing (Gilquin \& Granger, 2000). There are some studies on the advantage of concordancing in L2 teaching and learning. Supatranont (2005) used concordancing in comparison to the traditional approach to teach vocabulary to engineering L2 learners. The main findings of her study were that the L2 learners' average scores in the experimental group who were exposed to vocabulary through concordances were significantly higher than those in the comparison group.

\section{B. Research on Collocation and Concordancing}

Collocations are important aspects of L2 learning, but as Crystal (1992) stated, they cause difficulty in mastering L2 languages. Halliday and Hassan (1976) called collocations the most difficult part of lexical learning (1976). Ellis (2001), Moon (1992), and Nation (2001) state that collocations are an important aspect of language use and they differentiate native and nonnative speakers.

Sinclair (1991, cited in Jafarpour \& Koosha, 2006) argues that collocations are major features shown in concordances that are not presented completely in a dictionary.

Hill (2000) emphasizes the teaching of words with their collocations, and he says that students know, for example, the words hold and conversation, but may not know the collocation hold a conversation. There are many studies on the importance of collocations in an L2 (Lewis, 1997; Mounya, 2010), and the importance of concordances in teaching collocations is emphasized, too. Bahns (1993) stated that one reason that L2 learners lack receptive and productive knowledge of collocations is because of teaching methodology. Brown (1974) suggested a remedy that if the instructors choose collocations as the unit of practice instead of lexical items combined with grammar rules, then nonnative speakers can read and speak using collocations. According to him, one way to shift the teaching focus to language collocations is by using concordances to highlight these structures. One of such studies was conducted by Le (2010). His study employed two groups: one with concordancing and the other without concordancing. In this study, the L2 learners were asked to identify miscollocation. The result of the study was significantly in favor of the concordancing group. 
There are many studies on the effect of concordancing on learning collocations, but most of these studies are conducted on grammatical collocations than lexical ones. One of these studies is the one conducted by Jafarpour and Koosha (2006), investigating the effect of corpus on the collocation learning of Iranian L2 learners. The results of their study turned positive in comparison with the traditional method. Their areas of investigation were collocations of prepositions. Other kind of these studies are the ones conducted by Sun and Wang (2003) and Wang (2002) who tried to investigate how concordancing affect learning collocations, but their study was bound to grammatical collocations: verb + preposition collocations.

Wei (1999) suggested that more attention should be paid to lexical collocations, as these collocations include a wider range of words and they create more problems for L2 learners than grammatical collocations.

\section{Research on Concordancing, Collocation, and L2 Writing}

L2 learners face a major problem in writing. They do not know which words can be combined to form correct language. Therefore, there are a large number of miscollocations in their writings (Hill, 2000). According to Hill (2000), L2 learners often lose mark in their writings because they do not know the most common collocations of the words that are necessary in their writing. Studies on collocations in L2 writings conducted by Bahns and Eldaw (1993) as well as Youmei and Yun (2005) revealed that even advanced L2 learners have difficulties producing collocations.

The problem is mostly due to the approaches of teaching writing that emphasizes grammar. Some different methods (e.g., process approach, genre approach, and product approach) have been developed for effective instruction in writing. Among these different approaches, some have been concerned with the end product: Correct grammar and correct lexis and some have been concerned with the process of writing. None of these approaches have emphasized the importance of collocations in writing, and because collocations are central in vocabulary, an approach is needed that emphasizes this part of language. So, L2 learners make collocation mistakes in their writing because their instruction had been grammar focused and there had been no instruction of collocations. So, L2 teachers should attract L2 learners' attention to collocations because grammar and individual words are not sufficient in language proficiency.

Teaching collocations, as claimed by Cowie (1981), helps L2 learners in fluent writing. It facilitates L2 writing and makes it easier, more precise, and more natural.

Most studies on collocation production have used either cloze tests (Al-Zahrani, 1998) or translation tasks (Farghal \& Shunnq, 1999; Nesselhauf, 2005), so they are restricted in nature. An example of these studies is the one by Brashi (2006). He compared L2 learners' comprehension and production of verb-noun collocations using productive and receptive tests. The results revealed that the $\mathrm{L} 2$ learners were more proficient in comprehension than in production. Ying and Hendricks (2003) conducted a study in which they tried to raise the L2 learners' collocation through collocation awareness raising and investigated its effect on L2 learners' writing. They reached to positive results that collocation awareness-raising increased the quality of the L2 learners' work. Most of these studies have reached to the conclusion that collocation production causes great problems for L2 learners.

Ying (2009) performed a study on Chinese L2 learners. He aimed at examining the relation between collocations and coherence in writing. He concluded that there is a relationship between the correct use of collocations and coherence in writing. To overcome the problem, collocational knowledge of L2 learners should be developed to raise L2 proficiency. As a result, writing will become more fluent, precise, and meaningful because the learner knows collocations needed for writing.

The study conducted by Anthony (2006) was about the role of concordancing in writing instruction. In the study, L2 learners had to investigate the way in which language is used in natural contexts. He found the result that exposing L2 learners to language via context is more beneficial than just presenting language to them out of context.

The correct use of collocations is a parameter of advanced writing. There are a lot of miscollocations in L2 writings. This problem can be solved by raising L2 learners' attention to them.

Technology can be used as a way to increase L2 learners' knowledge of collocations and, at the same time, their writing. Having discussed the importance of writing, the role of collocations in writing, and the invention of concordancing, there are few studies on the use of concordancing in L2 writing. Few studies are conducted to show how technology helps L2 learners in approaching their writing process.

Yoon (2008) run a study with six L2 learners to investigate the effect of concordancing on L2 learners' writings. He reached to the conclusion that concordancing could increase the knowledge of collocations of L2 learners and also concordancing helped them solve their writing problems.

\section{Synonyms}

There are few studies on the importance of synonyms, collocations, and L2 learning, although the important role of collocations in L2 teaching and learning is identified. L2 learners should tell the difference between words with similar meanings. They should find collocation differences of near-synonyms and their frequent use. Near-synonyms cannot be substituted with one another.

The studies that focus on the erroneous use of near synonyms are limited in number (Lombard, 1997). Lombard's own study just focuses on the incorrect application of synonyms, but not on how to teach collocations of synonyms to L2 learners. Partington (1998) stated that presenting language through concordances to L2 learners can help them discriminate among semantically similar items that have different collocations. 
Martin (1984) stressed the importance of teaching synonyms and their common collocations to L2 learners. He stressed that teaching vocabulary via a list of synonyms ignores the differences among synonyms and causes L2 learners to consider two synonyms as interchangeable. He said that teaching synonyms and their collocations offer them the chance to compare and contrast new words and their collocations.

Yeh et al. (2007) employed concordancing to help L2 learners in lexical choice. Through concordancing, they could present the collocations of synonyms to L2 learners and reduce their problems of collocations of near-synonyms. They said that by collocations L2 learners can compare and discriminate among near-synonyms.

\section{METHODOLOGY}

In the study, teaching collocations of near-synonyms and L2 learners' comprehension and production of collocations were studied in two different approaches: the traditional approach and the corpus-based approach.

\section{A. Participants}

At first, 100 male and female L2 learners, aged 20-23, took the Michigan Test of English Language Proficiency (MTELP). Based on their scores, 90 were selected to participate in the study. In the next stage, the participants were given a test of collocations. The aim was to homogenize them in their collocation knowledge. The test was designed by the researchers and piloted for its reliability and validity. The researchers selected the participants above the mean score of the collocation test. Among these 90 participants, six were excluded from the study as they were not comparable with others in terms of collocation knowledge. Then, in the final stage, the participants were randomly divided into two groups: experimental and control.

\section{B. Materials}

The participants were given the MTELP. After that, they were presented with a test of collocations. In the next stage, they wrote on a topic which served as their prewriting and a test of collocations based on their errors in prewriting. This test served as their pretest. Then, they went under treatment and were given the same test as their posttest. They were also asked to write on another topic. This writing was their postwriting. The tests are provided in the Appendixes A, B, and $\mathrm{C}$.

\section{Procedure}

In the next stage, the participants were asked to write on a topic familiar to them, which served as their prewriting. After the prewriting, a test on collocations of synonyms was given to the participants to identify their knowledge of collocations of synonyms. The test was a two-choice test in which the participants were asked to choose the correct answer between the two choices provided. This test was given as the pretest and had 20 items with its reliability at 0.89 . The reliability was estimated through KR-21 formula. After that, the researchers began the treatment. The materials were developed to raise the participants' knowledge of English collocations. The materials consisted of different types of synonyms and their collocations along with the collocation exercises. The data for the experimental group were provided using BNC as the concordancing software. The aim was for the participants to explore the L2 patterns, and as part of their exercise, they were given new words with their synonyms to look up their collocations. The participants did the exercises by observing contexts of words in concordances. The printouts were given to the participants in the following format.

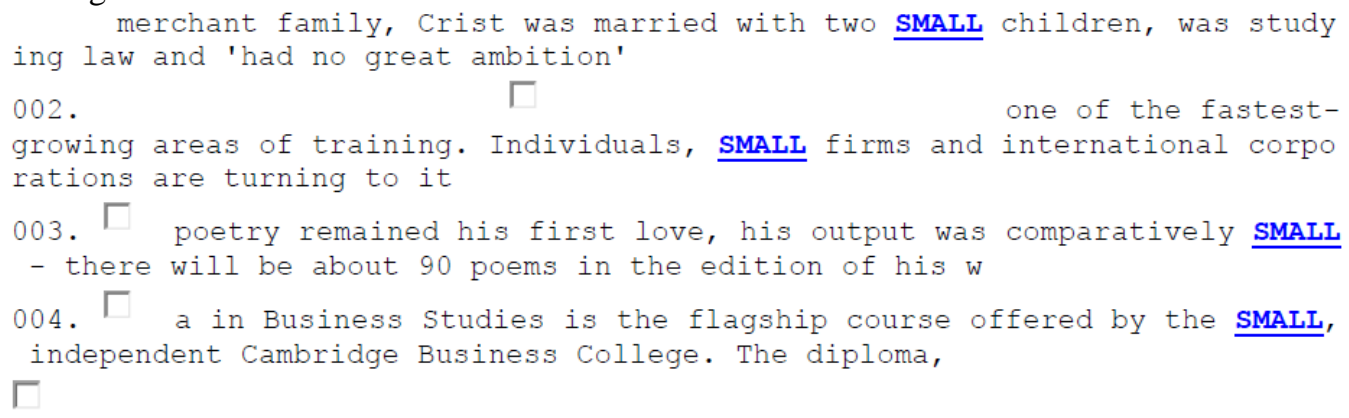

In this way, the participants in the experimental group could observe the different uses of the adjective small and compare them with the uses of its synonym little which were used interchangeably in their writing. 
and I thought Rudy Bond and his band of tuneful ward

heelers made " LITTLE Tin Box" even better than it was done by the New York cast; all

009. Г dds thus appear favorable that the secretary's neck may be spared.

e \# LITTLE RESISTANCE\# \& CAMBODIA'S chief of state, who has been accused o

010. $\square$ citizens a voice in the operation of their government and their par

ty. \# LITTLE WAR, BIG TEST\# Both Mr. K's have so far continued to speak sof

t

011. Г "cur" and "puppy" among other things, and at the crisis of his fi

t a LITTLE foxterrier stands before him and howls into his face.

In comparison, the control group was taught in traditional way. In other words, they were taught collocations explicitly by the teacher. They were given a definition of collocations, examples of different types of exercises, along with follow up exercises. The exercises were traditional such as matching words with their collocations, multiple-choice exercises that asked the participants to choose the correct collocation for each word, and correction exercises that asked them to correct the mistakes of given sentences. The materials for this group were taken from Oxford Collocations Dictionary (2005).

- Example \# 1: Correct these sentences.

- Many people were damaged in the earthquake.

- Example \# 2: Choose the correct collocation.

- I didn't know what to do when I got into my car and could not ..... my car. Start/begin

After the treatment, the posttest was administered to determine the effect of instruction. The pretest and the posttest were similar in number and content, but the place of the items on the pretest was different from the posttest. And, for the second hypothesis - the effect of instructions on the production of collocations- the study used postwriting after the treatment.

\section{DATA ANALYSIS}

At first, an independent $t$ test was performed on the pretest scores of the participants to see whether they had any differences at the beginning of the study or not. It was hypothesized that the participants were not different at the beginning of the study in terms of their collocational competence. The result of the $t$ test showed that there were not significant differences between the two groups at the beginning of the study. Table 1 is the presentation and discussion of this result:

TABLE 1

INDEPENDENT SAMPLE $T$ TEST FOR THE PRETEST SCORES OF BOTH EXPERIMENTAL AND CONTROL GROUPS

\begin{tabular}{|c|c|c|c|c|c|c|c|c|c|}
\hline & \multicolumn{2}{|c|}{$\begin{array}{l}\text { Levene's Test for } \\
\text { Equality of } \\
\text { Variances }\end{array}$} & \multicolumn{5}{|c|}{$t$ test for Equality of Means } & \multirow{2}{*}{\multicolumn{2}{|c|}{\begin{tabular}{|l|} 
\\
$\begin{array}{l}95 \% \text { Confidence } \\
\text { Interval of the Difference }\end{array}$ \\
\end{tabular}}} \\
\hline & \multirow[b]{2}{*}{$F$} & \multirow[b]{2}{*}{ Sig. } & \multirow[b]{2}{*}{$t$} & \multirow[b]{2}{*}{$d f$} & \multirow[b]{2}{*}{ Sig. (2-tailed) } & \multirow[b]{2}{*}{\begin{tabular}{|l} 
Mean \\
Difference
\end{tabular}} & \multirow[b]{2}{*}{\begin{tabular}{|l|} 
Std. Error \\
Difference
\end{tabular}} & & \\
\hline & & & & & & & & Lower & Upper \\
\hline $\begin{array}{l}\text { Equal Variances } \\
\text { Assumed } \\
\text { Equal Variances } \\
\text { Not Assumed }\end{array}$ & .000 & .990 & $\begin{array}{l}.222 \\
.222\end{array}$ & $\begin{array}{l}82 \\
80.444\end{array}$ & $\begin{array}{l}.825 \\
.825\end{array}$ & $\begin{array}{l}.09524 \\
.09524\end{array}$ & $\begin{array}{l}.42957 \\
.42957\end{array}$ & \begin{tabular}{|l}
-.75931 \\
-.75956
\end{tabular} & $\begin{array}{l}.94979 \\
.95004\end{array}$ \\
\hline
\end{tabular}

As it is evident from Table 1 , the $p$ value is not significant at $p<.05$. It means that the result of this test is not significant, and the null hypothesis that there will be no differences between the participants at the beginning of the study is not rejected. So, the participants were almost similar at the beginning of the study.

In the second stage, to see whether the participants had any progress at the end of the study or not, one paired-sample $t$ test was run on the pretest and posttest scores of the experimental group and one on the scores of the control group. The hypothesis was that they will not progress toward the end of the study. The results are provided in Tables 2 and 3 :

TABLE 2

PAIRED SAMPles T TEST ON THE PRETEST AND POSTTEST SCORES OF THE EXPERIMENTAL GrouP

\begin{tabular}{|c|c|c|c|c|c|c|c|c|}
\hline & \multicolumn{5}{|c|}{ Paired Differences } & \multirow[b]{3}{*}{$t$} & \multirow[b]{3}{*}{$d f$} & \multirow{3}{*}{$\begin{array}{l}\text { Sig } \\
\text { (2-tailed) }\end{array}$} \\
\hline & \multirow[b]{2}{*}{ Mean } & \multirow[b]{2}{*}{ Std. Deviation } & \multirow{2}{*}{$\begin{array}{l}\text { Std. Error } \\
\text { Mean }\end{array}$} & \multicolumn{2}{|c|}{$\begin{array}{l}\text { 95\% Confidence Interval } \\
\text { of the Difference }\end{array}$} & & & \\
\hline & & & & Lower & Upper & & & \\
\hline $\begin{array}{l}\text { Pair 1Experimental Pretest } \\
\text { Posttest }\end{array}$ & -1.59524 & 1.96381 & .30302 & -2.20721 & -.98327 & -5.264 & 41 & .000 \\
\hline
\end{tabular}


As the significance of the study shows the study is significant at $p<.05$, meaning that the above hypothesis is rejected and the experimental group has progressed toward the end of the study.

TABLE 3

PAIRED SAMPLES T TEST ON THE PRETEST AND POSTTEST SCORES OF THE CONTROL GROUP

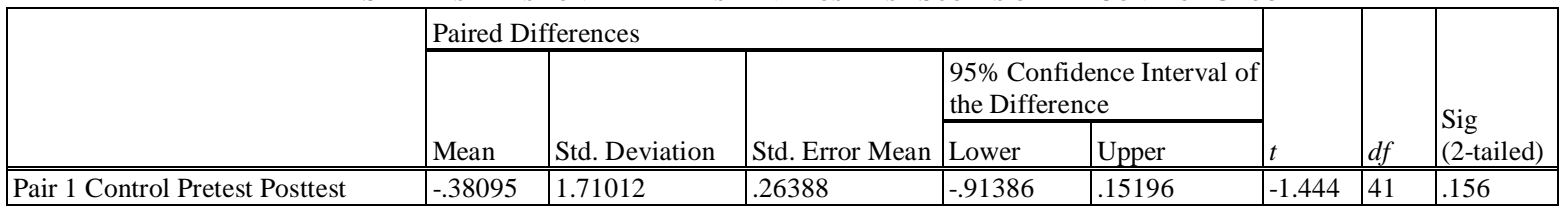

The result of the $t$ test is not significant at this part, so the above hypothesis is not rejected. It means that the control group had no progress at the end of the study, and the traditional approach could not raise the collocation knowledge of L2 learners.

As mentioned in the Methodology section, the first research question was a comparison of the learning effects of the corpus-based approach and the traditional approach in terms of comprehension of collocations. It was hypothesized that there would be no significant differences between comprehension of collocations in the experimental and control groups. To test this hypothesis, a collocation test was given to each group. A $t$ test with $(p<.05)$ was performed to examine the learning effects of the corpus-based approach and the traditional approach on collocation learning. Table 4 shows the result of the $t$ test carried out to test this hypothesis:

TABLE 4

INDEPENDENT SAMPLES T TEST FOR THE POSTTEST SCORES OF BOTH EXPERIMENTAL AND CONTROL GROUPS

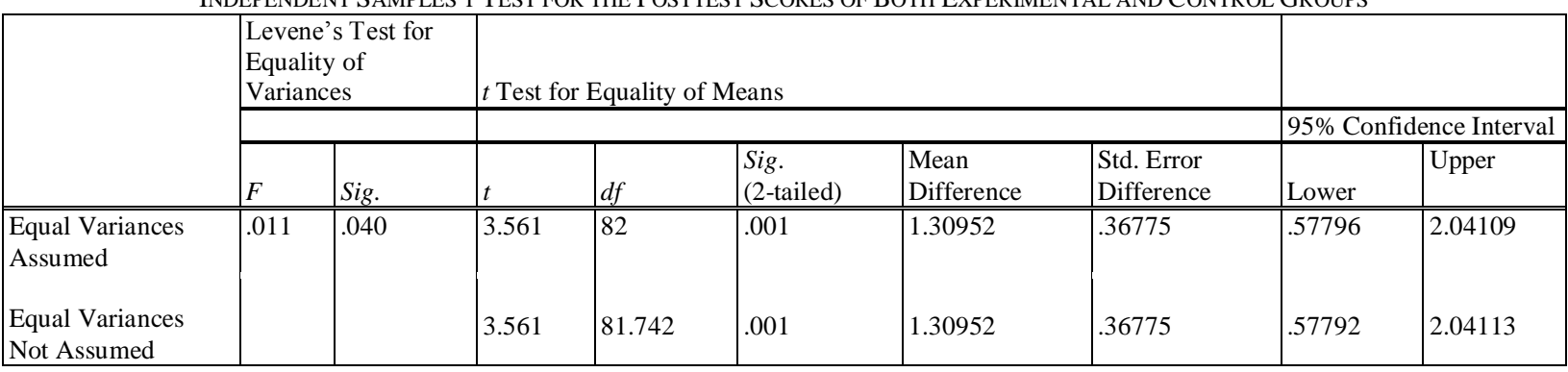

On testing this question, it was found that the $p$ value was significant at $p<.05$, indicating that the two approaches were different. The results of the $t$ test shows that the participants performed significantly better when they were taught through concordancing than the time they were taught without concordancing.

In a selection of the prewritings collected for the data analysis, a total of 343 collocation errors of synonyms were collected, and it was found that $180(52.47 \%)$ were incorrect in the prewriting of the experimental group and 163 $(47.53 \%)$ were incorrect in the prewriting of the control group. The data were analyzed against concordancing:

TABLE 5

COLLOCATION ERRORS OF SYNONYMS IN THE PARTICIPANTS' PREWRITINGS

\begin{tabular}{|l|l|l|}
\hline Groups of the Study & Number & Percentage \\
\hline \hline Experimental Group & 163 & 47.53 \\
\hline Control Group & 180 & 52.47 \\
\hline
\end{tabular}

From the prewritings, it is concluded that there was little difference between the experimental and control groups in number of the collocation errors of the synonyms.

After the treatment, their postwritings were analyzed using concordance. A total number of 139 collocation errors of synonyms were collected, and it was found that the number of collocation errors of synonyms in the postwritings of the experimental group was $54(38.84 \%)$ and that of the control group was $85(61.16 \%)$. The results are provided in the Table 6:

TABLE 6

COLLOCATION ERRORS OF SYNONYMS IN THE PARTICIPANTS' POSTWRITINGS

\begin{tabular}{|l|l|l|}
\hline Groups of the Study & Number & Percentage \\
\hline \hline Experimental Group & 54 & 38.84 \\
\hline Control Group & 85 & 61.16 \\
\hline
\end{tabular}

As shown in Tables 5 and 6, the comparison of the participants' prewritings and postwritings shows that when the participants were taught through concordancing, they could use collocations more appropriately. The results show that the number of collocational mistakes in the postwritings of the experimental group was less than those of the control group. After studying the essays, the researchers found that the participants made fewer collocation errors of synonyms 
when using the corpus for learning and when they were taught through concordancing approach than when they were taught though conventional approaches.

\section{DISCUSSION AND CONCLUSION}

Collocations, the cooccurrence of words, play an important role in language learning. According to Bahns and Eldaw (1993), collocational knowledge is necessary in fluent speech and writing, but it is difficult for L2 learners to acquire this aspect of language. Nesselhauf (2003) stated that even advanced L2 learners have difficulty with collocations and the frequency of the problems shows that L2 learners need instruction in these aspects of language.

Based on the findings of the study, the concordance-based method had more effect on collocation knowledge of L2 learners. The better comprehension and production of the participants in the experimental group is related to the efficiency of the method employed. In the corpus-based approach, collocations are highlighted in context, and L2 learners are told to pay attention to them. Attention to the context of the collocations gives L2 learners this knowledge that they cannot put any words they like next to each other in every context and different contexts need different collocations.

The study is in line the studies that have found the advantage of the corpus-based approach over the traditional approaches (Jafarpour \& Koosha, 2006). Jafarpour and Koosha conducted a study on the collocation learning of Iranian L2 learners and found positive relations between concordancing and collocation learning. The positive effect that the corpus-based approach had on the experimental group in terms of comprehension of collocations suggests that L2 learners' collocational knowledge and the way collocations are learned are closely and positively related.

Le (2010) also studied the effect of concordancing and traditional approach on the identification of miscollocations. The result of his study was strongly in favor of concordancing. Emphasizing the importance of collocations, Brown (1974) stated that more attention can be placed on collocations by using concordances to highlight collocations for the L2 learners.

There are a lot of other studies on the favor of concordancing and collocation learning (Le, 2010; Liu \& Jiang, 2009; Mounya, 2010). All these studies are in line with the present study and argue the importance of collocations over other methods on collocation learning of L2 learners.

L2 learners are not good writers, and one of the problems they encounter in their writing is the use of collocations. Collocational knowledge leads to fluent writing among L2 learners (Zhang, 1993). The problem is when L2 learners try to express themselves using collocations. They do not know how words go together. As it is evident from the current study, even advanced L2 learners have problems with collocations in the L2. They had a lot of problems with collocations in their prewriting. So, teaching collocations to L2 learners improves their writing. Corpus helps them learn the correct usage of words that is a problem in their writings.

In this study, the corpus was more effective in developing writing fluency of L2 learners. With the corpus-based approach, the L2 learners had access to authentic language through corpus and they could find their mistakes from the corpus. The reason is that corpus makes collocations more apparent to L2 learners. As Cobb (1999) states, when L2 learners search for the data themselves, they learn and remember them better and more. Also, teaching collocations to the L2 learners through the concordancing improved their collocational competence, reduced their miscollocations, and increased their awareness of how to combine words in order to be natural.

The literature is full of studies which show the positive relation between collocation teaching and writing proficiency. Mounya (2010) and Ying and Hendricks (2005) found the existence of a positive relation between L2 learners' use of collocations and writing proficiency. Mounya (2010) conducted an experiment to raise the L2 learners' writing proficiency by developing their collocational competence through an explicit teaching of collocations. Their pretest was full of collocation errors. After teaching collocations and conducting the experiment, he reached to the conclusion that teaching collocations would raise L2 learners' writing proficiency.

Conducting a study on the relation between collocations and writing fluency, Zhang (1993) reached to the conclusion that the collocations are among the factors that distinguish good and poor L2 writings.

Unfortunately, there are few studies on the relationship between concordancing and writing fluency. Anthony (2006) and Yoon (2008) are a few examples of such studies. To investigate the effect of concordancing on L2 learners' writings, Yoon (2008) conducted a study on six L2 learners. The result of his study was that concordancing increased awareness of the importance of collocations among L2 learners and caused them to pay more attention to collocations in their writings.

In the study conducted by Anthony (2006), the role of concordancing in writing was investigated. According to him, concordancing allowed L2 learners to observe L2 in context rather than in isolation which is more effective.

The present study supports the studies mentioned above, as it concludes the efficacy of concordancing over the traditional methods in improving the writing skill among L2 learners. The results of the study are also in line with the findings of Thurstun and Candlin (1998) who found the beneficiency of the corpus-based approach in teaching collocations and their use in writing.

Regarding teaching collocations, both groups progressed at the end, but the progress of the experimental group was more than the progress of the control group. All in all, the results of the study show that the corpus-based approach plays a positive role in L2 learners' learning and writing fluency and improves the quality of their writing. Differences 
in L2 learners' performance on collocation tests and their improvement in writing are related to the corpus-based approach. The writing proficiency of L2 learners improves as they discover the collocations of the words intended.

\section{ApPEndix A COLlocation Test}

Direction: Choose the correct choice.

1. What do you ..... for a living? do/make

2. He arrived exactly at $11, \ldots$. on time. Bang/exactly

3. They have no time. They work from ..... to dust. day/down

4. You'll forget it ..... by. When time comes/as time goes

5. What was wrong with him? He ..... drunk. got/became

6. Nobody in my class has ..... a lesson so far this year. missed/failed

7. You should always check your work carefully in case you have ..... some mistakes. done/made

8. I've been studying French for 6 months now, but I don't feel like I'm ..... progress. having/making

9. She placed her keys ..... on the table and sat down. slowly/gently

10. ..... a decision on whether to go or not to go is difficult for him. taking/making

11. It's nice to get out into the open/fresh air. I need a breath of ..... air. fresh/open

12. The health authority has ..... its decision and will now allow the treatment to go ahead. moved/altered

13. Excuse me, would you mind ..... a photo of me and my friend? take/catch

14. She is a ..... smoker. No wonder she coughs so much. heavy/strong

15. There was only a ..... wind, but it still blew a tree down in my garden. light/weak

16. I wish you would stop ..... such a mess in the kitchen. doing/making

17. He ..... a bad accident when he fell asleep while driving. He caused/made a bad accident when he fell asleep while driving.

\section{APPENDIX B COLLOCATION PRETEST}

Name:

Direction: Choose the correct choice.

Group:

1. Single parents ..... children without a partner's support are entitled to financial help from the government. grow/raise

2. I've never been very successful at ..... plants. raise/grow

3. Jack has already ..... a very good reputation as a talented lawyer. achieve/win

4. I hope your flight is on time tomorrow. Safe..... . trip/journey

5. He has to stay at home and take care of his wife. His wife is ....... a baby. expect/wait

6. The film ..... in a surprising way. begin/start

7. I don't have any ..... right now; in other words, I'm unemployed. work/job

8. My ..... brother is five years old. little/small

9. Because I was in a hurry, I took a ..... shower and went out. fast/quick

10. Are you satisfied with your new teacher? I'm ..... satisfied. downright/completely

11. Can you ..... the difference between these two pictures? tell/say

12. Facing a problem, many decide to ..... suicide. undertake/commit

13. The lion started to ..... when it heard the dog barking. roar/shout

14. At first her eyes filled with horror, and then she ..... into tears. burst/blow up

15. Let' go to (a)n ..... restaurant. I don't like this restaurant. open air/fresh air

16. I need a ..... computer. This one is too slow. strong/powerful

17. Everest is the ..... mountain in the world. highest/tallest

18. She placed her keys ..... on the table and sat down. slowly/gently

19. He was ..... by the movie. moved/affected

20. It's nice to get out into the open/fresh air. I need a breath of ..... air. fresh/open

\section{APPENDix C COLlocation POSTTEST}

Name:

Direction: Choose the correct choice.

Group:

1. He was $\ldots .$. by the movie. moved/affected

2. I've never been very successful at ..... plants. raise/grow

3. Jack has already ..... a very good reputation as a talented lawyer. achieve/win

4. The film ..... in a surprising way. begin/start

5 . Because I was in a hurry, I took a ..... shower and went out. fast/quick

6 . I need a ..... computer. This one is too slow. strong/powerful

7. I don't have any ..... right now, in other words I'm unemployed. work/job 
8. Are you satisfied with your new teacher? I'm ..... satisfied. downright/completely

9. My ..... brother is five years old. little/small

10. I hope your flight is on time tomorrow. Safe ..... . trip/journey

11. Can you ..... the difference between these two pictures? tell/say

12. Facing a problem, many decide to ..... suicide. undertake/commit

13. The lion started to ..... when it heard the dog barking. roar/shout

14. At first her eyes filled with horror, and then she ..... into tears. burst/blow up

15. Single parents ..... children without a partner's support are entitled to financial help from the government. grow/raise

16. Everest is the ..... mountain in the world. highest/tallest

17. Let' go to (a)n ..... restaurant. I don't like this restaurant. open air/fresh air

18. She placed her keys ..... on the table and sat down. slowly/gently

19. He has to stay at home and take care of his wife. His wife is ..... a baby. expect/wait

20. It's nice to get out into the open/fresh air. I need a breath of ..... air. fresh/open

\section{REFERENCES}

[1] Al-Zahrani, M. S. (1998). Knowledge of English lexical collocations among male Saudi college students majoring in English at a Saudi university. Unpublished doctoral dissertation, Indiana University of Pennsylvania, Pennsylvania.

[2] Anthony, L. (2006). Developing a freeware, multiplatform, corpus analysis toolkit for the technical writing classroom. Ieee Transactions on Professional Communication, 49(3), 25-32.

[3] Bahns, J. (1993). Lexical collocations: A contrastive view. ELT Journal, 47, 56-63.

[4] Bahns, J., \& Eldaw, M. (1993). Should we teach EFL students collocations? System, 21(1), 101-114.

[5] Benson, M., Benson, E., \& Ilson, R. (1997). The BBI dictionary of English word combinations. Amsterdam: John Benjamins Publishing Company.

[6] Bernardini, S. (2002). Exploring new directions for discovery learning. In B. Kettemannann \& G. Marko (Eds.), Teaching and learning by doing corpus analysis (pp. 165-182). Amsterdam: Rodopi

[7] Brashi, A. (2006). Collocability as a problem in L2 production. Reflection on English Language Teaching, 8(1), 21-34.

[8] Brown, D. (1974). Advanced vocabulary teaching: The problem of collocation. RELC Journal, 5(2), 1-11.

[9] Carter, R., \& McCarthy, M. (1999). Vocabulary and language teaching. London: Longman

[10] Celce-Murcia, M. \& Olshtain, E. (2000). Discourse and context in language teaching: A guide for language teachers. Cambridge: Cambridge University Press.

[11] Chambers, A. (2005). Integrating corpus consultation in language studies. Language Learning \& Technology, 9(2), 111-125.

[12] Chan, M. K. M. (2002). Concordancers and concordances: Tools for Chinese language teaching and research. Journal of the Chinese Language Teachers Association, 37(2), 1-58.

[13] Cheng, C. C., Huang, C. R., \& Lo, F. J. (2004). Extensive reading with guidance. An Interactive Workshop on Language eLearning. Retrieved May 23, 2009, from the World Wide Web: www.colocationamerica.com

[14] Cobb, T. (1999). "Breadth and depth of lexical acquisition with hands-on concordancing," Computer Assisted Language Learning, 12(4), 345-360.

[15] Cowie, A. (1981). The treatment of collocations and idioms in learners' dictionaries. Applied Linguistics, 2, $223-235$.

[16] Crystal, D. (1992). The Cambridge encyclopedia of language. Cambridge: Cambridge University Press.

[17] Ellis, N. C. (2001). Memory for language. In P. Robinson (Ed.), Cognition and second language instruction (pp. 33- 68). Cambridge: Cambridge University Press.

[18] Farghal, M., \& Shunnaq, A. (1999). Translation with reference to English and Arabic. A practical guide. Irbid-Jordan: Dar AlHilal for Translation.

[19] Firth, J. R. (1957). Papers in linguistics. London. Oxford University Press.

[20] Gilquin, G., \& Granger, S. (2000). How can DDL be used in language teaching? Retrieved April 23, 2007, from the World Wide Web: about.com/od/colocation/a/what_colocation.htm

[21] Granath, S. (1998). Using corpora in teaching English syntax to EFL students at the university level. In L. Burnard (Ed.), Proceedings of teaching and language corpora: TaLC98 (pp. 87-92). Oxford: Keble College.

[22] Halliday, M., \& Hasan, R. (1976). Cohesion in English. London: Longman.

[23] Hill, J. (2000). Revising priorities: From grammatical failure to collocational success. In M. Lewis (Ed.), Teaching collocation: Further developments in the lexical approach (pp. 47-69). London: Language Teaching Publications.

[24] Jafarpour, A., \& Koosha, M. (2006). Data- driven learning and teaching collocation of prepositions: the case study of Iranian EFL adult learners. Asian EFL Journal, 8(4), 192-209.

[25] Johns, T. (1991). Should you be persuaded — two samples of data-driven learning materials. In T. Johns \& P. King (Eds.), Classroom Concordancing (Vol. 4).

[26] Le, T. H. (2010). Learning lexical collocations with concordancing and scaffolding. Unpublished master's thesis, University of Groningen.

[27] Lewis, M. (1997). Implementing the lexical approach: Putting theory into practice. Hove: Language Teaching Publications.

[28] Lombard, R. J. (1997). Nonnative speaker collocation: A corpus-driven characterization from the writing of native speakers of Mandarin. Unpublished doctoral dissertation, Arlington, Texas.

[29] Moon, R. (1992). Textual aspects of fixed expressions in learners' dictionaries. In P. J. L. Arnaud \& H. Bejoint (Eds.), Vocabulary and applied linguistics (pp. 13-27). London: Macmillan.

[30] Mounya, A. (2010). Teaching lexical collocations to raise proficiency in foreign language writing. Unpublished master's thesis, Guelma University, Algeria 
[31] Nation, I. S. P. (2001). Learning vocabulary in another language. Cambridge: Cambridge University Press.

[32] Nesselhauf, N. (2005). Collocations in a learner corpus. Amsterdam: John Benjamins.

[33] Palmer, H. (1933). Second interim report on English collocations. Tokyo: Kaitakusha.

[34] Parastuti, A. (2005). The negative transfer of English collocations written by the students of Gunadarma University.

[35] Partington, A. (1998). Patterns and meaning: Using corpora for English language research and teaching. Philadelphia, PA: John Benjamins.

[36] Sinclair, J. M. (1991). Corpus, concordance, collocation. Oxford: Oxford University Press.

[37] Sinclair, J. (2003). Corpora for lexicography. In P. V. Sterkenberg (Ed.), A practical guide to lexicography. Amsterdam: John Benjamins.

[38] Souza Hodne, L. (2009). Collocations and teaching: Investigating word combinations in two English textbooks for Norwegian upper secondary school students. Unpublished doctoral dissertation, Toronto University.

[39] Sun, Y. C., \& Wang, L.Y. (2003). Concordancers in the EFL classroom: Cognitive approaches and collocation difficulty. Computer Assisted Language Learning, 16(1), 83-95.

[40] Supatranont, p. (2005). A comparison of the effects of the concordance-based method and the conventional teaching methods on engineering students' English vocabulary learning. Unpublished doctoral dissertation, Chulalongkorn University.

[41] Thurstan, J., \& Candlin, C. N. (1998). Concordancing and the teaching of the vocabulary of academic English. English for Specific Purposes, 17(3), 267-280.

[42] Tribble, C., \& Jones, G. (1990). Concordances in the classroom: A resource book for teachers. U. K: Longman.

[43] Wang, L.Y. (2002). Effects of inductive and deductive approach on EFL learning collocations patterns by using concordances. Unpublished master's thesis, National Yunlin University of Science and Technology, China, Institute of Applied Foreign Languages.

[44] Wei, Y. (1999). Teaching collocations for productive vocabulary development. Paper presented at the Annual Meeting of the Teachers of English to Speakers of Other Languages, New York.

[45] Yeh, Y., Liou, H., \& Li, Y. (2007). Online synonym material and concordancing for EFL college writing. Computer Assisted Language Learning, 20(2), 131-152.

[46] Ying, S. (2009). Study on collocations in English writing by Chinese students. Journal of Sino-US English Teaching, 6(3), 2530.

[47] Ying, Y., \& Hendricks, A. (2003). Collocation awareness in the writing process. Paper presented at the international conference, Hong Kong University.

[48] Yoon, H. (2008). More than a linguistic reference: The influence of corpus technology on L2 academic writing. Language Learning \& Technology, 12(2), 31-48.

[49] Youmei, G., and Yun, Z. (2005). A Tentative corpus-based study of collocations acquisition by Chinese English language learners. Canadian Social Science, 1(3), 105-112.

[50] Zarei, A. A., \& Golami, V. (2007). The effect of partial synonymy on L2 vocabulary learning, Iranian Journal of Language Studies, 1(2), 73-88.

[51] Zhang, X. (1993). English collocations and their effect on the writing of native and nonnative college freshmen. Unpublished doctoral dissertation, Indiana University of Pennsylvania, Pennsylvania, USA.

Ali Akbar Jafarpour is an assistant professor at Shahrekord University. His area of research includes ESP, ELT, and SLA research. He has published articles in both national and international journals as well as a book on academic writing. Also, he has given lectures in national and international conferences.

Mahmood Hashemian is an assistant professor at Shahrekord University. His area of research includes cognitive-semantic linguistics, sociolinguistics, and applied linguistics. He has published articles in academic journals such as JTLS, IJAL, IJ LS, JALS, Linguistik Online, JLTR, TPLS, Iranian EFL Journal, IJEL, and International Journal of Social Sciences. Also, he has given lectures in several national and international conferences such as TELLSI (4, 7, 8, 9, \& 10), LDP2010/ LDP2013 (Ahvaz, Iran), ELT in the Islamic World (Tehran, Iran), $2^{\text {nd }}$ International Language Conference 2011 (Malaysia), the $1^{\text {st }}$ Thammasat ELT International Conference: Voices in ELT (Thailand), $1^{\text {st }}$ International Akdeniz Language Studies Conference 2012 (Turkey), and $1^{\text {st }}$ Conference on Language Learning \& Teaching: An Interdisciplinary Approach (Mashhad, Iran).

Sepideh Alipour is now an M.A. TEFL student at Shahrekord University. His areas of interest include CALL and ESP. And, she has been teaching English at various language institutes for more than three years. 